\title{
The Upper Triassic Chedabucto Formation, Guysborough County, Nova Scotia: depositional and tectonic context
}

\author{
Lawrence H. Tanner ${ }^{1}$ and David E. Brown ${ }^{2}$ \\ 'Department of Geography and Geosciences, Bloomsburg University, Bloomsburg, PA 17815 USA \\ ${ }^{2}$ Canada-Nova Scotia Offshore Petroleum Board, 1791 Barrington Street, Halifax, NS B3J 3K9 Canada
}

\author{
Date Received: December 17, 1998 \\ Date Accepted: June 1, 1999
}

\begin{abstract}
The Chedabucto Formation of presumed Late Triassic age crops out at the western end of the Orpheus basin. The formation consists of interbedded conglomerate, sandstone, and mudstone interpreted as the deposits of sand-dominated braided streams, and clast-supported conglomerate interpreted as debris-flow deposits derived from nearby fault talus. The facies and presumed age of the Chedabucto Formation are similar to that of the Wolfville Formation in the Minas subbasin of the Fundy rift basin. These facies may also be present in the lower portion of the Eurydice Formation at the base of the sedimentary section in the offshore Orpheus basin. The location of the outcrops of the Chedabucto Formation suggests that a continuous belt of sedimentation connected the Orpheus and Fundy rift basins in the Late Triassic, forming a "broad terrane" extending from eastern New Brunswick to the Scotian Shelf. The Chedabucto Formation was deposited primarily by an axial river system flowing eastward from the Fundy rift basin to the Orpheus basin. The Minas subbasin of the Fundy rift basin and the Orpheus basin are interpreted as segments of a larger transtensional basin formed by synchronous obliquesinistral motion on the bounding Cobequid-Chedabucto Fault. Basin inversion in the Middle Jurassic probably initiated uplift, resulting in the erosional isolation of the Fundy and Orpheus basins.
\end{abstract}

La Formation de Chedabucto, présumément de l'époque du Trias tardif, affleure à l'extrémité ouest du bassin d'Orphée. La Formation est constituée de mudstones, de grès et de conglomérats interlités interprétés comme les dépôts de cours d'eau en tresse à prédominance de sable ainsi que de conglomérats clastiques interprétés comme des dépôts de coulées de débris provenant de talus de failles voisins. Le faciès et l'âge présumé des affleurements de la Formation de Chedabucto sont semblables à ceux de la Formation de Wolfville dans le bassin secondaire Minas du bassin tectonique de Fundy. Ces faciès pourraient en outre être présents dans la partie inférieure de la Formation d'Eurydice à la base de la section sédimentaire du bassin marin d'Orphée. L'emplacement des affleurements de la Formation de Chedabucto laisse supposer qu'une ceinture continue de sédimentation a raccordé les bassins tectoniques d'Orphée et de Fundy au cours du Trias tardif, formant ainsi un large terrane qui s'étendait de l'Est du Nouveau-Brunswick à la Plate-forme Scotian. La Formation de Chedabucto a principalement été déposée par un système riverain axial coulant en direction est du bassin tectonique de Fundy au bassin d'Orphée. Les chercheurs interprètent le bassin secondaire Minas du bassin tectonique de Fundy et le bassin d'Orphée comme des segments d'un bassin de transition transversale formé par un mouvement oblique senestre synchrone s'étant exercé sur la faille de délimitation de Cobequid-Chedabucto. Une inversion du bassin au cours du Jurassique moyen a probablement amorcé un soulèvement qui a entraîné un isolement par érosion des bassins de Fundy et d'Orphée.

[Traduit par la rédaction]

\section{INTRODUCTION}

Outcrops of brown sublitharenite sandstone, conglomerate, and red mudstone on the north shore of Chedabucto Bay were initially mapped by Stevenson (1959) and informally described by Klein $(1960,1962)$, who applied the name Chedabucto Formation. Olsen (1988) recognized that these outcrops represent sediments associated with Triassic riftbasin formation resulting from the breakup of Pangea and designated the location of these outcrops as the "Chedabucto basin," but without delimiting the size or stratigraphy of this "basin."

This paper revises the type section of the Chedabucto Formation and proposes that these outcrops represent erosional remnants of a belt of continuous sedimentation that extended eastward from the present coast of New Brunswick, across Nova Scotia, and out onto the Scotian Shelf during the Late Triassic and Early Jurassic. Further, we propose that the offshore Orpheus basin and the Fundy rift basin were part of a single transtensional basin complex controlled by subsidence along the Cobequid-Chedabucto fault (CCF). Support for this hypothesis also includes the tectonic and stratigraphic similarities of the Fundy rift and Orpheus basins, and paleocurrent data from the Fundy rift basin.

Recent debate of the merits of the "broad-terrane hypothesis," the concept that now erosionally separated basins of the Newark Supergroup were once joined, has been inspired by study of the distribution of rift-related, Lower Jurassic flood basalts in eastern North America (McHone 1996, 1997; Huber 1997). The hypothesis of a "broad terrane" was initially proposed by Russell (1878) to account for the seemingly paired distribution of Mesozoic basins with mirror-image structural geometry and stratigraphic similarities. The concept evolved to focus specifically on the proposed continuity of the Newark and Hartford basins (Russell 1880; Sanders 1963). More recently, Rosendahl et al. (1986) proposed that basins of this type are separated by a high-relief accommodation zone, which would discount the possibility of their continuity. Other 
studies have focused on the relationship between the Hartford and Pomperaug basins, suggesting that the latter is an erosional outlier of the former (Krynine 1950; Hubert et al. 1978; Weddle and Hubert 1983), although sedimentary evidence, including facies distribution and source area provenance, now seems to favor an interpretation of depositionally isolated basins (Huber and McDonald 1992; Hubert et al. 1992; Horne et al. 1995; Huber 1997).

\section{TeCtonic SeTting}

Outcrops of the Chedabucto Formation are located just west of the offshore Orpheus basin and about $130 \mathrm{~km}$ east of the easternmost outcrops of the Fundy rift basin. Aside from geographic proximity, the Orpheus and Fundy rift basins share a common tectonic element, the Cobequid-Chedabucto fault, a crustal transform that juxtaposed Meguma and Avalonian terranes by dextral movement in the Paleozoic (Fig. 1) (Keppie 1982a). Northwest-southeast extension began in the Middle Triassic and caused reactivation of the CobequidChedabucto fault with a sinistral-oblique sense of movement (Withjack et al. 1995), with sinistral offset estimated from 10 to $15 \mathrm{~km}$ (Withjack et al. 1995; Wade et al. 1996), to as much as $75 \mathrm{~km}$ (Keppie 1982a).

The Orpheus basin forms a structural trough on the northern Scotian Shelf, widening and plunging eastward from Chedabucto Bay to the Laurentian subbasin (MacLean and Wade 1992; Fig. 1). Interpretations of industry seismic (Tankard and Welsink 1989; Wade and MacLean 1990; MacLean and Wade 1992; Withjack et al. 1995) and magnetic data (Keen et al. 1990) indicate that the northern margin of the Orpheus basin coincides with the boundary between the Avalon and Meguma terranes. The northern margin of the basin is bounded by the eastern extension of the CobequidChedabucto fault with approximately $8 \mathrm{~km}$ of vertical displacement (Tankard and Welsink 1989). The southern margin consists of a series of discontinuous faults antithetic to the Cobequid-Chedabucto fault. Sedimentation in the Orpheus basin started in the Norian or earlier, as dated by the palynology of well cuttings (Jansa et al. 1980).

\section{BASIN-FILL SEQUENCE}

The rift-fill sequence of the Orpheus basin has been reviewed in detail (Tanner and Brown, in press) and is summarized in Fig. 2. Mesozoic sediments were deposited unconformably on a basement consisting of varied lithologies of Late Proterozoic to Permo-Carboniferous age, including metasedimentary, metavolcanic, igneous intrusive, siliciclastic, carbonate, and evaporite rocks. Exploratory wells were drilled in this basin primarily on structures at the basin margins or on salt structures. Consequently, no wells have been drilled through the entire basin-fill sequence of approximately $10 \mathrm{~km}$.

The Eurydice Formation is the designation for Late Triassic redbeds in the Orpheus basin, but only the uppermost part of the Eurydice Formation has been drilled. The type section for the formation is the Eurydice P-36 well which penetrated the upper $600 \mathrm{~m}$ of the formation, leaving approximately $2000 \mathrm{~m}$ of the formation undrilled. Cuttings and core samples from this well consist of red mudstone and very fine- to fine-grained sandstone containing ripple laminations, anhydrite nodules, and sandpatch fabric. Coarse, presumably alluvial facies have been drilled in the lower part of the Eurydice Formation in the Emerald basin on the Scotian Shelf (Welsink et al. 1989) and may comprise the undrilled lower Eurydice Formation in the Orpheus basin as well (Wade and MacLean 1990; Tanner and Brown, in press).

\section{Chedabucto Formation}

\section{Introduction}

The Chedabucto Formation crops out at several locations on the northern shore of Chedabucto Bay, between McCaul Island and Porper Point (Fig. 1). These outcrops of brown sublitharenite sandstone, conglomerate, and red mudstone were mapped by Stevenson $(1959,1960,1964)$, who recognized a similarity to Triassic strata of the Fundy rift basin and considered them equivalent to the Annapolis Formation, the now-abandoned designation for the Triassic strata of the Fundy rift basin. The Chedabucto Formation was named by Klein $(1960,1962)$, who cited a tentative Late Triassic age based on fragmental osseus remains. However, no systematic paleontological or palynological studies have been conducted on these strata.

\section{Type Section}

The type section chosen by Klein (1960), but never formally described and published, comprises about 66 meters of strata exposed just northeast of McCaul Island (Figs. 1, 3). Bedding through much of this section strikes northeast at $030^{\circ}$ to $050^{\circ}$, and dips southeast at $20^{\circ}$ to $40^{\circ}$ (Fig. 4a), obscuring lateral facies relationships. Small-scale reverse faults with meters of displacement (Figs. 3, 4b) and gentle anticlinal folds are present in the lower part of the section, near McCaul Island.

The section (Fig. 3) consists of the following facies interbedded in generally noncyclic fashion: (1) Massive sandstone, fine- to coarse-grained, commonly pebbly, occurs in yellow-brown, nongraded beds up to $3 \mathrm{~m}$ thick (30\%). (2) Fining-upward massive sandstone, from coarse- to finegrained, occurs in beds up to $1.5 \mathrm{~m}$ thick $(16 \%)$; (3) Coarsegrained sandstone with shallow $(20 \mathrm{~cm})$ gravel-filled lenses and isolated clasts up to $10 \mathrm{~cm}$ in diameter, occurs in beds up to $3.6 \mathrm{~m}$ thick $(12 \%)$. Locally, the shallow lenses contain abundant rounded, white quartz pebbles. (4) Fine-grained to muddy sandstone with $\mathrm{cm}$-scale fine, drab-colored (grayishgreen) root traces, micritic nodules, or burrows, is often mottled by grayish-green reduction spheroids. This facies occurs in beds up to $1.8 \mathrm{~m}$ thick (10\%). (5) Mudstone beds up to $1.9 \mathrm{~m}$ thick, which are reddish-brown and massive or locally contain desiccation cracks, sand-filled burrows, cmscale arcuate slickensides that are typically clay-lined, root traces up to $10 \mathrm{~cm}$ long, and $\mathrm{cm}$-scale micritic nodules $(10 \%)$ (Fig. 4c). (6) Claystone forms a single bed $2.6 \mathrm{~m}$ thick containing cm-scale, arcuate slickensides (5\%). (7) Planarcross-bedded sandstone is coarse to pebbly, in beds up to 1.2 $\mathrm{m}$ thick (8\%). (8) Clast-supported conglomerate forms typically fining-upward beds up to $0.5 \mathrm{~m}$ thick containing 


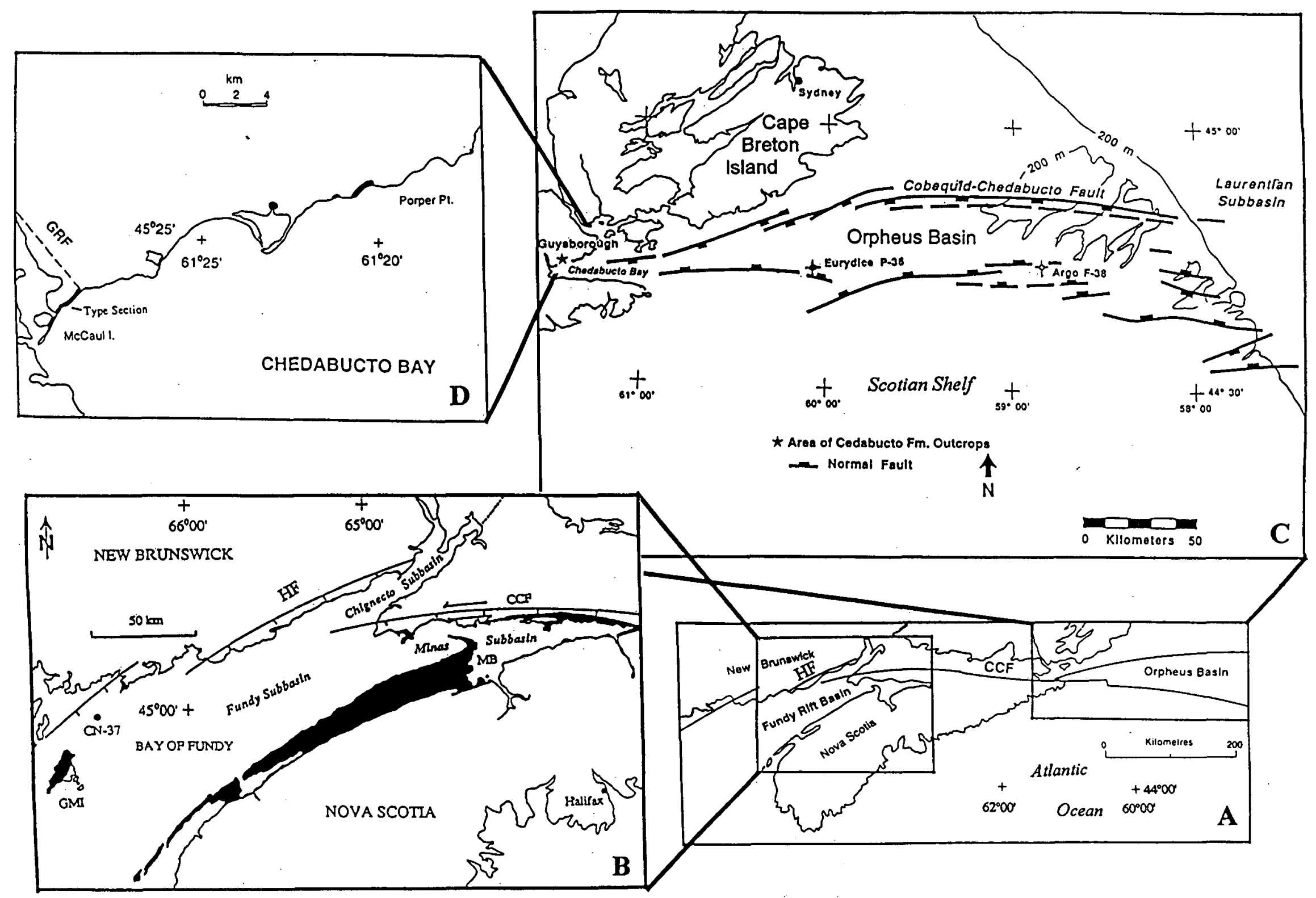

Fig. 1. Key locations and structural features described in this paper. A. Major tectonic elements of the Fundy rift basin-Orpheus basin system; $\mathrm{CCF}=\mathrm{Cobequid-Chedabucto}$ fault, $\mathrm{HF}=$ Headland fault. B. Geometry and Fundy Group outcrop locations (shaded black) in the Fundy rift basin; MB=Minas (geographic) Basin, CN-37=Chinampas N-37 well, GMI=Grand Manan Island; structural elements include the Cobequid-Chedabucto fault, bounding the northern margins of the Minas and Fundy subbasins, and the NE-trending Headland fault of the Chignecto and Fundy subbasins. C. Key structural elements of the Orpheus basin. D. Location of outcrops of the Chedabucto Formation, including the type section. GRF=Guysborough River fault. 


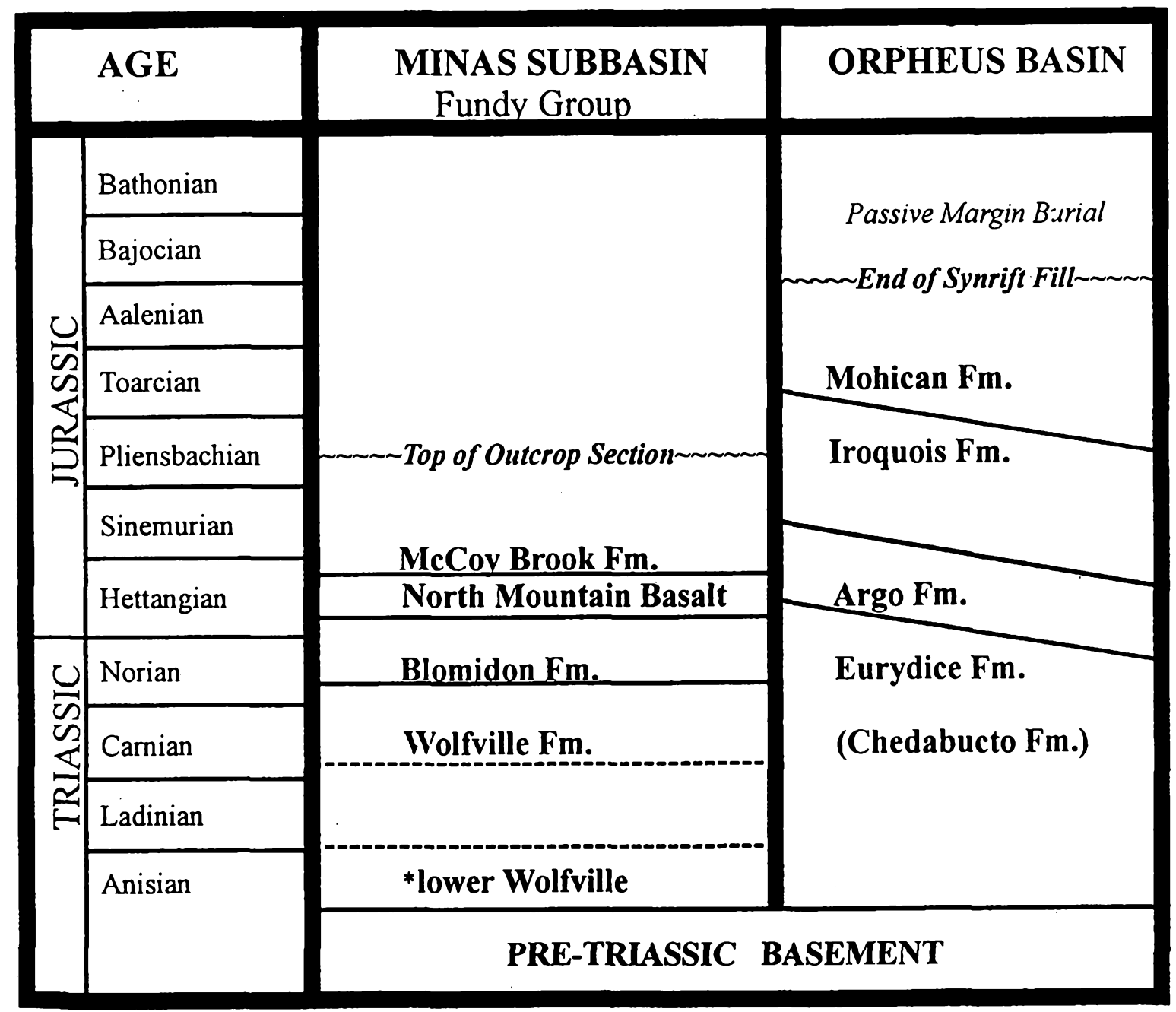

Fig. 2. Current stratigraphies of the Minas subbasin and Orpheus basin (Olsen, 1997; Tanner and Brown, in press). The "lower Wolfville" comprises strata that are temporally and structurally separated from the main body of the formation. Formation contacts in the Orpheus basin are shown as diachronous, decreasing in age to the west. The lower strata of the Eurydice Formation are unexplored and the lower age limit is therefore unconstrained. Equivalence with the Chedabucto Formation is speculative.

clasts of metamorphic provenance up to $70 \mathrm{~cm}$ in diameter (3\%) (Fig. 4a). This facies is most prominent lower in the section (meters 8-14). (9) Trough-crossbedded sandstone with thin $(10 \mathrm{~cm})$ sets occurs interbedded with massive sandstone (6\%). Contacts between beds are conformable to erosional. Numerous sub-meter- to meter-scale, fining-upward sequences, consisting of conglomerate or coarse sandstone to mudstone, are visible in the section.

\section{Other Outcrops}

East of the type section, $40 \mathrm{~m}$ of strata, comprising poorly organized conglomerate beds, 0.3 to $1.5 \mathrm{~m}$ in thickness (Fig. 4d), are exposed in discontinuous sections that are in faulted contact with Carboniferous (Canso Group) strata to the east. Thicker beds consist of matrix-supported conglomerate and are inversely-graded to nongraded. Thinner beds have an open-framework fabric cemented by calcite. Clast size ranges up to $30 \mathrm{~cm}$. Mudstone beds up to $0.9 \mathrm{~m}$ thick, containing root traces, are interbedded with the conglomerate. Additional outcrops of redbeds occur farther east on the shore of
Chedabucto Bay (Fig. 1). These outcrops consist of weathered sandstone and pebble conglomerate, lacking sedimentary structures, in sections with a maximum thickness of $30 \mathrm{~m}$.

\section{Interpretation}

The conglomerate and crossbedded sandstone facies in the type section indicate depositional processes involving the downstream migration of subaqueous bars and dunes. The small scale of the bedforms (maximum $30 \mathrm{~cm}$ ) indicates that the channels were shallow. The erosional bases of many beds and the presence of gravel-filled scours suggest that the streams flowed in multiple channels that migrated laterally in response to significant changes in discharge, eroding the largely noncohesive floodplain and mid-channel bar deposits. Frequent channel migration and abandonment resulted in deposition of the common submeter- to meter-scale, finingupward sequences. This distribution of facies is consistent with an interpretation of deposition by a sand-dominated stream system. The relatively minor gravel load was deposited as longitudinal bars and as lag. The dominance of massive 

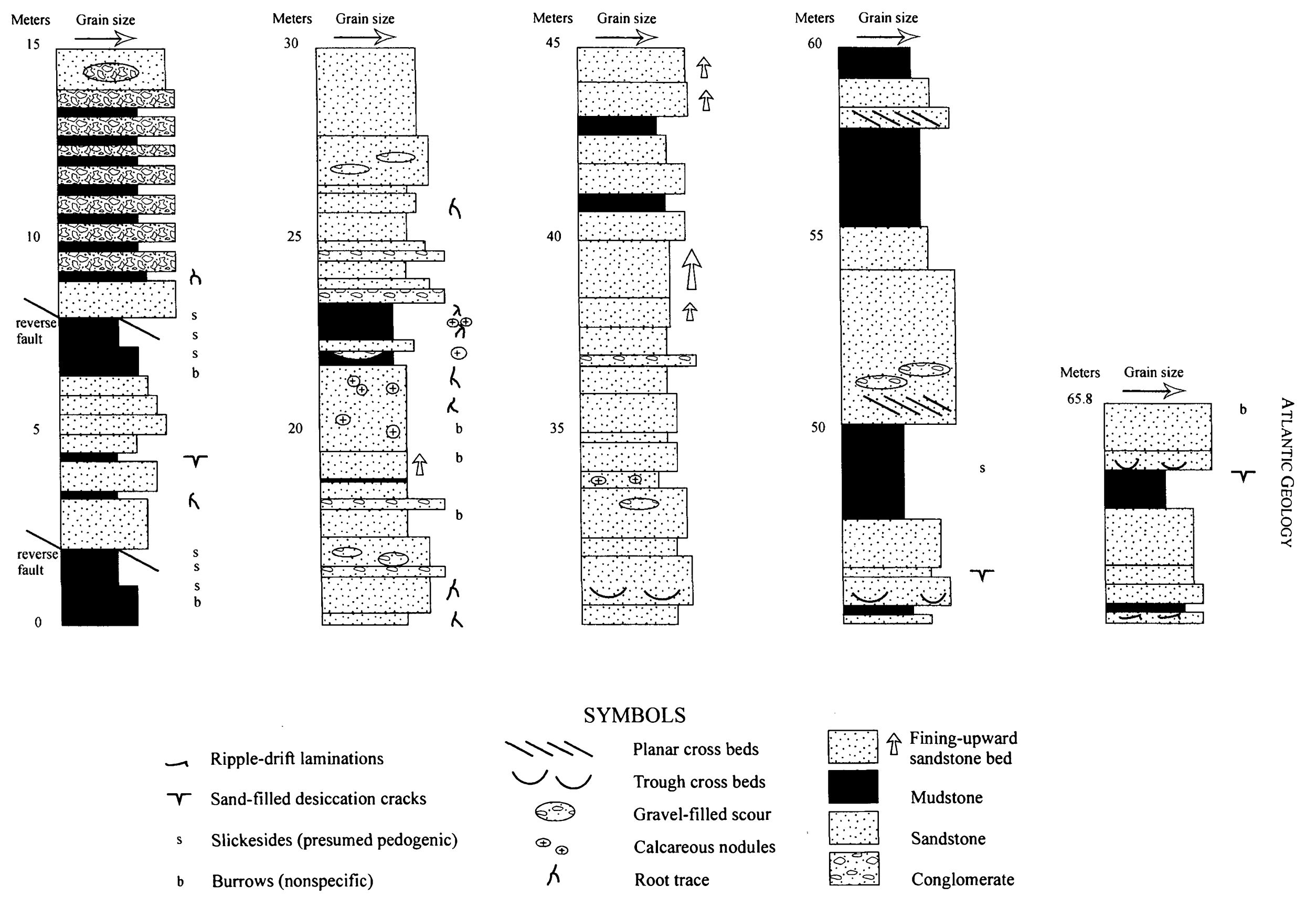

Fig. 3. Type section of the Chedabucto Formation northeast of McCaul Island (Fig. 1) on the shore of Chedabucto Bay measured at the bed level. 


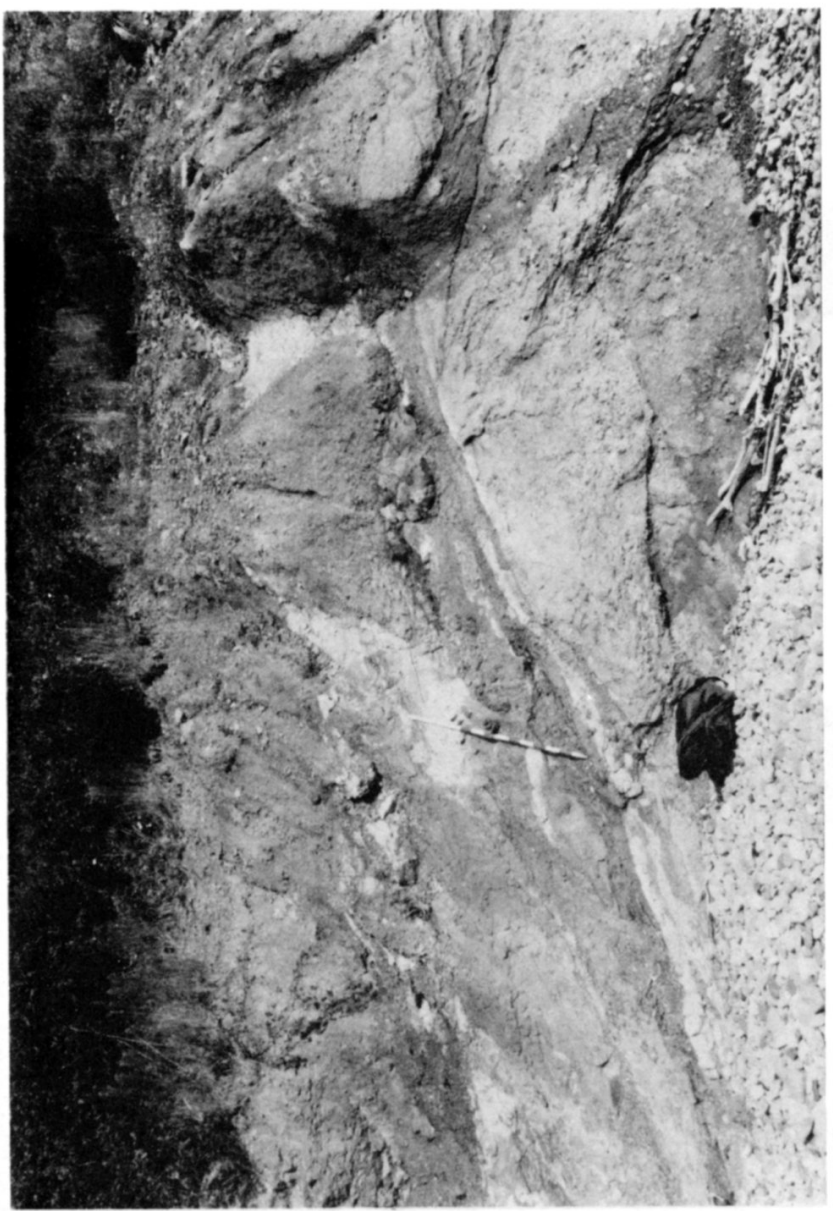

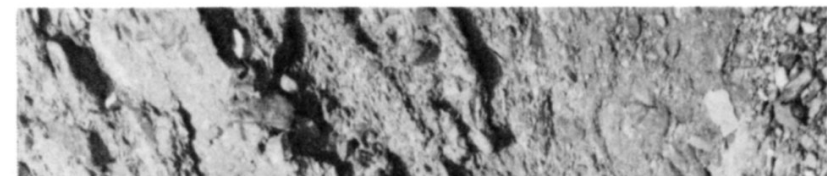

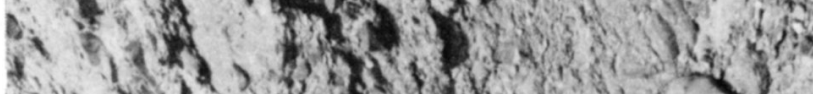

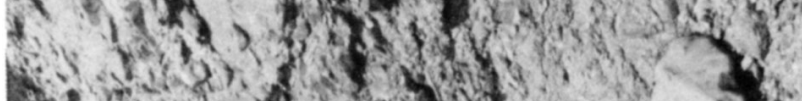

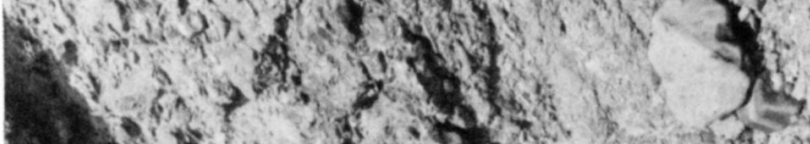

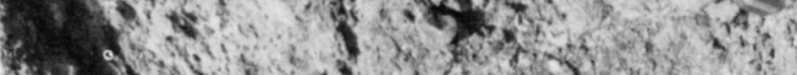

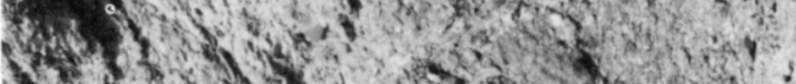

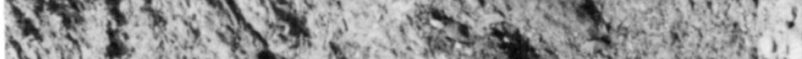

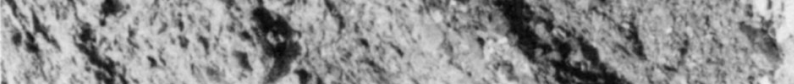

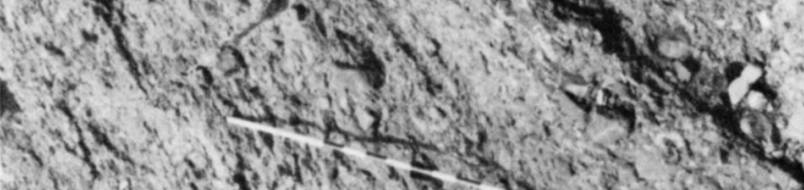

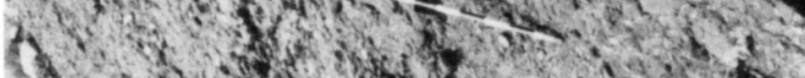

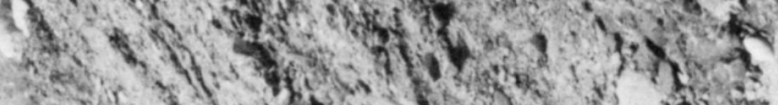
(5)
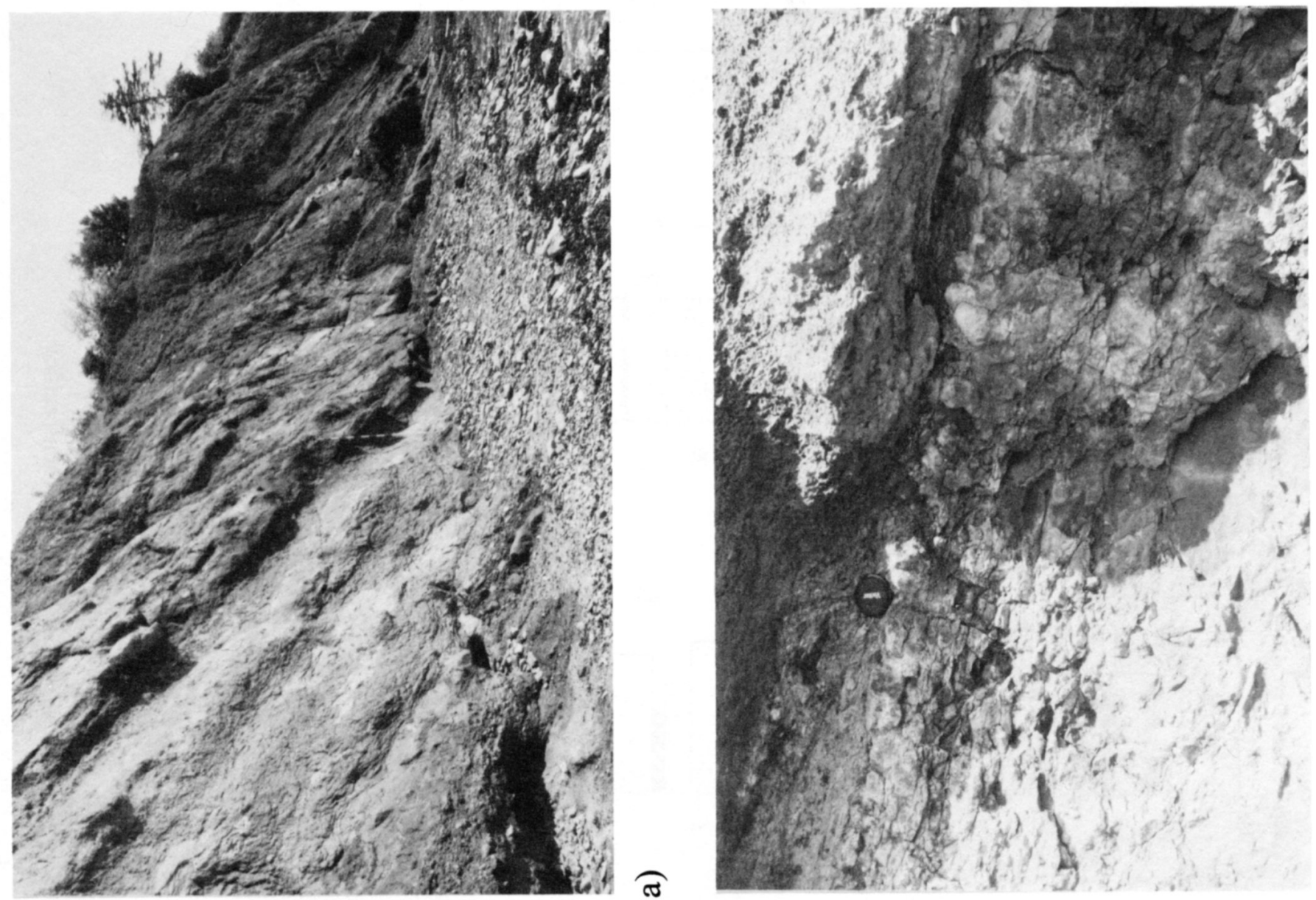
sandstone in the measured section may be attributed to the advanced state of weathering of the outcrop, rather than depositional processes that produce massive beds, such as grain flow. Complete obliteration of sedimentary structures by bioturbation in such a substantial proportion of the section is possible but unlikely in streams with a large seasonal discharge fluctuation. Reliable paleocurrent indicators in the Chedabucto Formation type section are few $(n=4)$ and variable (NW to SE).

Pedogenic processes on the floodplain are clearly indicated by the presence of paleosol features, such as pedogenic slickensides, drab root traces, and micritic nodules in fine-grained sandstones and mudstones (Fig. 4c). The coalescing nodule horizons are interpreted as the $\mathrm{K}$ horizons of Stage III caliche paleosols (Gile et al. 1966). Together, these features indicate sediment deposition under strongly seasonal subhumid to semi-arid climate conditions. The Late Triassic Wolfville Formation in the Minas subbasin consists of similar strata of crossbedded sandstone, minor conglomerate, and interbedded mudstone containing caliche paleosols (Hubert and Forlenza 1988; Tanner, in press).

The matrix-supported conglomerate outcropping east of the type section exhibits some characteristics associated with debris-flow deposits, such as basal inverse grading and outsize clasts (Nemec and Steele 1984). The interbedded openframework conglomerate may represent fluvial reworking of debris-flow gravel. The source of the debris in these deposits may have been nearby scarps associated with the Guysborough River fault (GRF, Fig. 1), a northwest-trending subparallel splay of the Cobequid-Chedabucto Fault (Keppie 1982a, b). Similar conglomerate facies in the Jurassic McCoy Brook Formation in the Minas subbasin are interpreted as the deposits of debris flows transporting fault-derived talus (Tanner and Hubert, 1991).

The sections of the Chedabucto Formation occur near the western end of the Orpheus basin, but these outcrops differ substantially in lithology from the fine-grained strata comprising the upper part of the Eurydice Formation in the Eurydice P-36 well. The Chedabucto Formation more closely resembles the coarse clastic units of the Wolfville Formation cropping out to the west in the Minas subbasin, whereas the upper Eurydice Formation is lithologically and temporally similar to the Norian-Hettangian Blomidon Formation which overlies the Wolfville Formation. In the Minas subbasin, the Wolfville and Blomidon Formations constitute a major finingupward megasequence of alluvial-fan to braided-stream to sandflat/playa deposition resulting from basin enlargement (Olsen et al. 1989; Mertz and Hubert 1990; Schlische and Olsen 1990). A similar sequence may exist in the Eurydice Formation of the nearby Orpheus basin, consisting of a coarse, lower member equivalent to the Chedabucto and Wolfville Formations, and a finer-grained upper member, similar to the
Blomidon Formation.

\section{Discussion}

The Orpheus and Fundy rift basins formed when NW-SE directed extensional forces caused reactivation of the Cobequid-Chedabucto fault with combined sinistral strike-slip and normal components (Withjack et al. 1995). We suggest that the resulting subsidence formed an elongated transtensional basin of which the Orpheus and Fundy basins are the proximal and distal ends. Fossils in strata on the north side of the Minas subbasin indicate that subsidence began as early as Anisian time in the Fundy rift basin (Fig. 2; Baird 1986; Olsen 1988).

The Fundy rift basin to the west of the study area consists of three distinct structural components: the east-trending Minas subbasin is a transtensional basin bounded to the north by the Cobequid-Chedabucto fault and related strike-slip and oblique-slip faults; and the northeast-trending Chignecto and Fundy subbasins, simple half-grabens bounded to the northwest by southeast-dipping normal faults of the Headland fault system (Fig. 1) (Withjack et al. 1995; Wade et al. 1996). These subbasins are separated by the Cobequid-Chedabucto fault; the Chignecto subbasin lies to the north, the Fundy subbasin lies to the south. Mesozoic redbeds and basalt formations of the Fundy Group crop out at the margins of the subbasins primarily as cliffs on the Fundy coasts of Nova Scotia and New Brunswick.

Dip-slip movement on reactivated Alleghenian-Variscan basement thrusts, presumably penecontemporaneous with reactivation of the Cobequid-Chedabucto Fault, caused subsidence of the Fundy subbasin with a maximum vertical offset estimated from at least $6 \mathrm{~km}$ (Withjack et al. 1995) to at least $10 \mathrm{~km}$ (Wade et al. 1996). Nearly $3.5 \mathrm{~km}$ of Mesozoic section were drilled in the Chinampas N-37 well in the Fundy subbasin, and interpretation of industry seismic data suggests that the Fundy Group may be as much as $10 \mathrm{~km}$ thick beneath the Bay of Fundy in the depocenter of the Fundy subbasin (Wade et al. 1996).

The Minas subbasin opens westward into the structurally distinct Fundy subbasin half-graben, but structurally, the Minas subbasin more closely resembles the Orpheus basin than the other subbasins of the Fundy rift basin. Subsidence in the Minas subbasin, where the strike-slip component of offset was greater than the normal component, was estimated at 2 to $3 \mathrm{~km}$ by Wade et al. (1996). The Fundy Group is relatively thin in the Minas subbasin, approximately $1 \mathrm{~km}$, compared to its thickness in the other subbasins (Olsen and Schlische 1990).

The Orpheus basin was proximal to the main rift axis and therefore subsided more deeply than the Minas subbasin at the distal end of an elongate basin. The Minas subbasin and the

Fig. 4. a) View of the Chedabucto Formation from about $8 \mathrm{~m}$ in the measured section (Fig. 3). Beds closest to the camera are clast-supported conlomerates interbedded with mudstones. The trend of the shoreline is NE; beds are dipping SE. $1.5 \mathrm{~m}$ staff for scale. b) Reverse fault of unknown displacement at $2 \mathrm{~m}$ in the measured section (Fig. 3) superimposing mudstone (left) over stratigraphically higher massive sandstone (right). Stratigraphic top is to the right. $1.5 \mathrm{~m}$ staff for scale. c) Lens cap rests on layer of coalescing micritic nodules, 3 to $7 \mathrm{~cm}$ in diameter, in mudstone facies beneath conglomerate at $23 \mathrm{~m}$ in measured section. This section represents a truncated Stage III caliche paleosol profile (of Gile et al., 1966). d) Decimeter- to meter-scale matrix- and clast-supported conglomerate beds cropping out NE of the type section along the shore of Chedabucto Bay. Beds are unstratified and contain clasts up to $30 \mathrm{~cm}$ in diameter. A few beds display basal inverse grading. 
region to the east of it therefore formed a shallow basin segment between the more deeply subsided extant basins. Consequently, synrift fill was thinner in this region than in the Fundy subbasin or the Orpheus basin, accounting for the thinning of Mesozoic strata eastward in the Minas subbasin and the almost total lack of outcrop farther east, aside from the limited exposures of strata of the Chedabucto Formation.

Evidence of a hydrologic connection between the Minas subbasin and the Orpheus basin is provided by fluvial paleocurrents from the Wolfville Formation in the Minas subbasin, which display a bimodal distribution. To the east of the Avon River estuary, streams flowed westward, toward the Fundy subbasin (Hubert and Forlenza 1988). The mean azimuth of about $060^{\circ}$ for 1471 fluvial paleocurrent measurements from outcrops of the Wolfville Formation to the east of this divide (Hubert and Forlenza 1988) indicate stream drainage toward the Orpheus basin in the Late Triassic (Carnian to Norian). While statistically significant numbers of paleocurrent measurements are not available from the weathered outcrops of the Chedabucto Formation, the exisiting paleocurrents (NW-SE) are not inconsistent with an interpretation of sediment transport from the Minas subbasin to the Orpheus basin during Wolfville-Chedabucto-Eurydice deposition, supporting the interpretation of a "broad terrane" encompassing the Fundy rift and Orpheus basins.

We consider the location of these outcrops and the paleocurrent data from the Minas subbasin, as well as the similarities in lithology and facies to the Wolfville Formation, as evidence of an axial river system flowing eastward in an elongate transtensional basin, similar to the system that existed during the Late Triassic in the Hartford basin. The proximity of the Chedabucto section to the Orpheus basin and the analogous evolution of the Orpheus basin and Minas subbasin also suggest that the unexamined lower portion of the Eurydice Formation is a time- and facies-equivalent of the Wolfville and Chedabucto Formations. Slower subsidence of a structural high between the two basins may have caused deposition of a thinner section, ultimately leading to erosional isolation of the basins.

Subsidence and synrift sedimentation in the entire region may have been terminated by the Middle Jurassic by basin inversion triggered by the onset of sea-floor spreading (Withjack et al. 1995, 1998; Wade et al. 1996). The reverse faults, folds, and steep dips observed in the Chedabucto section are the manifestations of tectonic compression and are similar to features in the Fundy rift basin, such as hangingwall anticlines and reverse faults, interpreted as resulting from basin inversion (Withjack et al. 1995, 1998). Withjack et al. (1998) estimated uplift of the Fundy subbasin to be about 1.5 $\mathrm{km}$ during inversion. This vertical rise is consistent with the estimate of 1 to $2 \mathrm{~km}$ of burial for sandstones of the Jurassic McCoy Brook Formation in the Minas subbasin (Tanner 1994). Northwest-southeast directed compression, as modeled by Withjack et al. $(1995,1998)$ may have resulted in similar uplift of the hanging wall along the length of the CobequidChedabucto Fault, resulting in the removal of the thinned synrift sedimentary section between the extant basins.

Similarities in the tectonic histories of the Fundy rift and Orpheus basins have been noted by previous authors (Withjack et al. 1995; Wade et al. 1996; Tanner and Brown, in press). This parallel basin evolution appears to have resulted in similar styles of sediment deposition operating contemporaneously in both basins, at least until the Early Jurassic. Whereas it is impossible to prove that the start of sedimentation was coeval in both basins, synrift basin fill was clearly under way in the Orpheus and Fundy rift basins by the Norian. An initial period of rapid deposition of coarse fluvial clastics in the Carnian-Norian was succeeded by a period of fine-grained lacustrine/playa sedimentation in the Norian. This fining-upward transition is considered typical in the evolution of rift-basin fill, possibly resulting from basin enlargement and the consequent decrease in depositional gradient on the basin floor (Schlische and Olsen 1990). Continued opening of the rift system allowed Tethyan waters to invade the proximal end of the transtensional basin, resulting in deposition of evaporites of the Argo Formation during the Early Jurassic (Tanner and Brown, in press).

Stratigraphic similarities between basins of the Newark Supergroup are a common pattern and were central to the original hypothesis of a "broad terrane" (Russell 1880), but by themselves are no indication of depositional continuity. The location of the Chedabucto Formation, however, demonstrates that an area of redbed deposition existed between the Fundy rift and Orpheus basins. Alternatively, the Chedabucto Bay outcrops could represent synrift fill of an isolated "pocket" subbasin formed by oblique-sinistral offset on the Guysborough River fault. Timing of basin opening in this case need not coincide with the initial movement on the CobequidChedabucto Fault and could simply represent a transfer of extensional strain at a later time. However, while the matrixsupported conglomerate facies of the formation was undoubtedly derived locally, the more characteristic massive to crossbedded sandstone and mudstone facies suggest deposition by streams that were a part of a much broader alluvial system that originated a substantial distance from the locus of deposition. More rigorous dating of the Chedabucto Formation by identification of definitive osseus remains or palynomorphs, if possible, could greatly clarify the relationship of these strata to the regional setting.

\section{CONCLuSIONS}

The Chedabucto Formation consists of a series of outcrops that represent deposition by sand-rich, braided streams flowing eastward from the Minas subbasin towards the Orpheus basin. Outcrops of clast-supported conglomerate represent the deposits of debris flows formed by the remobilization of nearby fault-derived talus. The braidedstream facies of the Chedabucto Formation is a lateral equivalent of similar facies in the Upper Triassic Wolfville Formation of the Minas subbasin. We suggest that similar facies occur in the lower part of the Upper Triassic-Lower Jurassic Eurydice Formation in the Orpheus basin.

We interpret a single, elongate transtensional basin, bounded to the north by the Cobequid-Chedabucto fault, that extended from the Fundy rift half-graben system to the Laurentian subbasin. The eastern side of the basin was traversed by an axial river system that deposited the Wolfville and Chedabucto Formations during the Late Triassic (Carnian to Norian). The Orpheus basin, proximal to the main rift, 
subsided more deeply than the more distal Minas subbasin. Similarly, the $1 \mathrm{~km}$ total thickness of the Fundy Group in the Minas subbasin is thinner by almost an order of magnitude than in the Fundy subbasin depocenter, reflecting the difference in subsidence along the oblique-slip CobequidChedabucto fault at its western margin, compared to the subsidence along the normal-slip Headland fault system bounding the Fundy subbasin. We believe that subsidence of the area between the Fundy and Orpheus basins was probably less than that of the extant basins, and that subsequent uplift and erosion of possibly $2 \mathrm{~km}$ of section, as interpreted from the Fundy basin, completed the isolation of these basins, fragmenting the "broad terrane."

\section{ACKNOWLEDGEMENTS}

The authors wish to thank R. Schlische for his insightful comments on an earlier version of this manuscript, $M$. Withjack for her helpful review, and G. Williams for kind editorial assistance.

BAIRD, D.M. 1986. Middle Triassic herpetofauna in Nova Scotia: Friends of the Newark Newsletter, 10, p. 10.

GILE, L.F., PETERSON, F.F., AND GROSSMAN, R.B. 1966. Morphological and genetic sequences of carbonate accumulation in desert soils. Soil Science, 10, pp. 347-360.

HORNE, G.S., MCDONALD, N.G., LETOURNEAU, P.M., AND DE BOER, J.Z. 1995. Paleoenvironmental traverse across the early Mesozoic Hartford rift basin, Connecticut. Connecticut Geological and Natural History Survey Guidebook 7, pp. D1D28.

HUBER, P. 1997. Comment on broad terrane Jurassic flood basalts across northeastern North America. Geology, 25, pp. 191-192.

HuBER, P., AND MCDONALD, N.G. 1992. Revised stratigraphy and paleontology of the early Mesozoic Pomperaug basin (Newark Supergroup), western Connecticut. Geological Society of America Abstracts with Programs, v. 24, no. 7, pp. A357-A358.

HUBERT, J.F., AND FORLENZA, M.F. 1988. Sedimentology of braidedriver deposits in Upper Triassic Wolfville redbeds, southern shore of Cobequid Bay, Nova Scotia, Canada. In TriassicJurassic Rifting and the Opening of the Atlantic: Continental Breakup and the Origin of the Atlantic Passive Margins, Part A. Edited by W. Manspeizer. Elsevier Publishers, Amsterdam, pp. 231-248.

HuberT, J.F., ReED, A.A., DOWDAll, W.L., AND GILChRIST, J.M. 1978. Guide to the Mesozoic redbeds of central Connecticut. Connecticut Geological and Natural History Survey Guidebook 4.

Hubert, J.F., Feshbach-Meriney, P.E., AND SMith, M.A. 1992. The Triassic-Jurassic Hartford rift basin, Connecticut and Massachusetts: evolution, sandstone diagenesis, and hydrocarbon history. American Association of Petroleum Geologists Bulletin, 76, pp. 1710-1734.

JANSA, L.F., BUJAK, J.P., AND WILliaMS, G.L. 1980. Upper Triassic salt deposits of the western North Atlantic. Canadian Journal of Earth Sciences, 17, pp. 547-559.

KeEn, C.E., LonCarevic, B.D., ReID, I., WoOdside, J., HaworTh, R.T., AND WILliamS, H. 1990. Tectonic and geohpysical overview; chapter 2. In Geology of the Continental Margin of Eastern Canada. Edited by M.J. Keen and G.L. Williams. Geological Survey of Canada, Geology of Canada no. 2, pp. 3185.

KEPPIE, J.D. 1982a. The Minas Geofracture. In Major Structural Zones and Faults of the Northern Appalachians. Edited by P.St.
Julien and J. Beland. Geological Survey of Canada, Special Paper 24, pp. 263-280.

KePPIE, J.D. 1982b. Tectonic Map of the Province Nova Scotia. Department of Mines and Energy, Halifax, Nova Scotia.

KLEIN, G. D. 1960. Stratigraphy, sedimentary petrology, and structure of Triassic sedimentary rocks, Maritime Provinces, Canada. Unpublished Ph.D. thesis, Yale University, New Haven, Connecticut.

KLEIN, G.D. 1962. Triassic sedimentation, Maritime provinces, Canada. Geological Society America Bulletin, 73, pp. 11271146.

KRYNINE, P.D. 1950. Petrology and Origin of the Triassic Sedimentary Rocks of Connecticut. Connecticut State Geological and Natural History Survey Bulletin 73.

MACLEAN, B.C. AND WADE, J.A. 1992. Petroleum geology of the continental margin south of the islands of St. Pierre and Miquelon, offshore Canada. Bulletin of Canadian Petroleum Geology, 40, pp. 222-253.

MCHONE, J.G. 1996. Broad-terrane Jurassic flood basalts across northeastern North America. Geology, 24, pp. 319-322.

MCHONE, J.G. 1997. Reply on broad-terrane Jurassic flood basalts across northeastern North America.Geology, 25, p. 192.

MERTZ, K.A., AND HUBERT, J.F. 1990. Cycles of sand-flat sandstone and playa-lacustrine mudstone in the Triassic-Jurassic Blomidon redbeds, Fundy rift basin, Nova Scotia: implications for tectonic and climatic controls. Canadian Journal of Earth Sciences, 27, pp. 442-451.

NEMEC, W., AND STEELE, R.J. 1984. Alluvial and coastal conglomerates: their significant features and some comments on gravelly mass-flow deposits. In Sedimentology of Gravels and Conglomerates. Edited by L.H. Koster and R.J. Steele. Canadian Society of Petroleum Geologists, Memoir 10, pp. 1-31.

OLSEN, P.E. 1988. Paleontology and paleoecology of the Newark Supergroup (early Mesozoic, eastern North America). In Triassic-Jurassic Rifting and the Opening of the Atlantic: Continental Breakup and the Origin of the Atlantic Passive Margins, Part A. Edited by W. Manspeizer. Elsevier Publishers, Amsterdam, pp. 185-230.

OLSEN, P.E. 1997. Stratigraphic record of the early Mesozoic breakup of Pangea in the Laurasia-Gondwana rift system. Annual Reviews in Earth Science, 25, pp. 337-401.

OLSEN, P.E., AND SCHISCHE, R.W. 1990. Transtensional arm of the early Mesozoic Fundy rift basin: penecontemporaneous faulting and sedimentation. Geology, 18, pp. 695-698.

OlSEN, P.E., SCHLISCHE, R.W., AND GORE, P.J.W. 1989. Tectonic, depositional, and paleoecological history of early Mesozoic rift basins, eastern North America. Guidebook to the International Geological Congress, Field Trip T-351.

RoSENDAHL, B.R., BURgeSS, C.F., SANDER, S., AND LAMBIASSE, J. 1986. Structural symptoms of continental rifting (abstract). American Association of Petroleum Geologists Bulletin 70, p. 641.

RUSSELL, I.C. 1878. On the physical history of the Triassic formation in New Jersey and the Connecticut Valley. Annals of the New York Academy of Science, 1, pp. 220-254.

RUSSELL, I.C. 1880. On the former extent of the Triassic formation of the Atlantic states. American Naturalist, 14, pp. 703-712.

SANDERS, J.E. 1963. Late Triassic tectonic history of northeastern United States. American Journal of Science, 261, pp. 501-524.

SCHLISCHE, R.W., AND OLSEN, P.E. 1990. Quantitative filling models for continental extensional basins with applications to the early Mesozoic rifts of eastern North America. Journal of Geology, 98, pp. 135-155.

StEvEnSON, I.M. 1959. Chedabucto Bay. Geological Survey Canada, Map 3-1959.

STEVENSON, I.M., 1960. New occurrence of Triassic sedimentary rocks in Chedabucto Bay area, Nova Scotia. Geological Survey 
of America Bulletin, 71, pp. 1807-1808.

STEvenson, I.M. 1964. Chedabucto Bay. Geological Survey Canada, Map 1156-A.

TANKARD, A.J., AND WelSINK, H.J. 1989. Mesozoic extension and styles of basin formation in Atlantic Canada. In Extensional Tectonics and Stratigraphy of the North Atlantic Margin. Edited by A.J. Tankard and H.R. Balkill. American Association of Petroleum Geologists, Memoir 46, pp. 175-195.

TANNER, L.H. 1994. Distribution and origin of clay minerals in the Lower Jurassic McCoy Brook Formation, Minas Basin, Nova Scotia. Sedimentary Geology, 92, pp. 229-239.

TANNER, L.H. (in press). Pedogenic record of Early Jurassic climate in the Lower Jurassic McCoy Brook Formation, Fundy rift basin, eastern Canada. In Aspects of Triassic-Jurassic Rift Geoscience. Edited by P. LeTourneau and P.E. Olsen. Columbia University Press.

TANNER, L.H., AND BROWN, D.E. (in press). Tectonostratigraphy of the Orpheus graben, Scotian basin, offshore eastern Canada and relationship to the Fundy rift basin. In Aspects of TriassicJurassic Rift Geoscience. Edited by P. LeTourneau and P.E. Olsen. Columbia University Press.

TANNER, L.H., AND HUBERT, J.F. 1991. Basalt breccias and conglomerates of the Lower Jurassic McCoy Brook Formation, Fundy basin, Nova Scotia: differentiation of talus and debrisflow deposits. Journal of Sedimentary Petrology, 61, pp. 15-27.

WADE, J.A., AND MACLEAN, B.C. 1990. The geology of the southeastern margin of Canada, In Geology of the Continental Margin of Eastern Canada. Edited by M.J. Keen and G.L.
Williams. Geological Survey of Canada, Geology of Canada no. 2 , pp. 167-238.

Wade, J.A., Brown, D.E., Traverse, A., AND Fensome, R.A. 1996. The Triassic-Jurassic Fundy basin, eastern Canada: regional setting, stratigraphy and hydrocarbon potential. Atlantic Geology, 32, pp. 189-231.

WeDDLE, T.K., AND HUBERT, J.F. 1983. Petrology of the Upper Triassic sandstones of the Newark Supergroup in the northern Newark, Pomperaug, Hartford, and Deerfield basins. Northeastern Geology, 5, pp. 8-22.

Welsink, H.J., DWYER, J.D., AND KNIGHT, R.J. 1989. Tectonostratigraphy of the passive margin off Nova Scotia, In Extensional Tectonics and Stratigraphy of the North Atlantic Margins. Edited by A.J. Tankard and H.R. Balkwill. American Association of Petroleum Geologists, Memoir 46, pp. 215-231.

Withuack, M.O., Olsen, P.E., AND SCHLISCHE, R.W. 1995. Tectonic evolution of the Fundy rift basin, Canada: evidence of extension and shortening during passive margin development. Tectonics, 14 , pp. 390-405.

WithJaCK, M.O., SChlische, R.W., AND OlSEN, P.E. 1998. Diachronous rifting, drifting, and inversion on the passive margin of central North America: an analog for other passive margins. American Association of Petroleum Geologists Bulletin, 82, pp. 817-835.

Editorial Responsibility: G.L. Williams 